\title{
PROBLEMATIKA YURIDIS SISTEM ALOKASI HUKUM DALAM PENGAWASAN HAKIM
}

\section{The Juridical Problems of Allocation Legal System in the Judge Control}

\author{
Muhtadi \\ Fakultas Hukum, Universitas Lampung \\ email: muhtadi.1977@gmail.com
}

\begin{abstract}
The procedure Oversight Judge (How It Treats People) is regulated by an internal mechanism by the Supreme Court as an institution builder through the remedies and oversight mechanisms of behavior, as well as the external monitoring Judicial Commission behavior of justices and judges in the Supreme Court. While the constitutional judges monitored internally without the involvement of outside agencies. There is injustice setting norms supervision of judges (How It Distribute). If the justices and courts in Supreme Court monitored externally by Judicial Commission and internally by the Supreme Court, Court only supervised institution's own internal artificial.
\end{abstract}

Keywords: Judge Supervision, and System Allocation Law

\begin{abstract}
abstrak
Prosedur Pengawasan Hakim (How It Treats People) diatur dengan mekanisme internal oleh MA sebagai pembina institusi melalui mekanisme upaya hukum dan pengawasan perilaku, serta KY sebagai pengawas eksternal terhadap perilaku hakim agung dan hakim di bawah MA. Sedangkan hakim konstitusi diawasi secara internal tanpa keterlibatan lembaga luar. Terdapat ketidakadilan pengaturan norma pengawasan hakim (How It Distribute). Jika hakim agung dan badan peradilan dalam lingkungan MA diawasi secara eksternal oleh KY dan internal oleh MA, MK hanya diawasi lembaga buatan internal sendiri.
\end{abstract}

Kata Kunci : Pengawasan Hakim, dan Sistem Alokasi Hukum

\section{A. Pendahuluan}

Sejak diundangkan dan diberlakukan Undang-Undang No. 14 Tahun 1970 tentang Kekuasaan Kehakiman kemudian diganti dengan UndangUndang No. 35 Tahun 1999 tentang Kekuasaan Kehakiman, yang kemudian dicabut dan diganti oleh Undang-Undang Republik Indonesia No. 4 Tahun 
2004 tentang Kekuasaan KeHakiman. ${ }^{1}$ Yang kemudian mengalami perubahan dan sampai sekarang diatur dalam Undang- Undang No. 48 Tahun 2009 tentang Kekuasaan Kehakiman, yaitu: ${ }^{2}$

"Kekuasaan Kehakiman adalah kekuasaan Negara yang merdeka untuk menyelenggarakan peradilan guna menegakkan hukum dan keadilan berdasarkan Pancasila dan Undang-Undang Dasar Negara Republik Indonesia Tahun 1945, demi terselenggaranya Negara Hukum Republik Indonesia".

Adanya reformasi pada tahun 1998, Undang-Undang Dasar 1945 sebagai hukum tertinggi mengalami perubahan. Perubahan Undang-Undang Dasar 1945 telah membawa perubahan dalam kehidupan ketatanegaraan khususnya kekuasaan kehakiman. ${ }^{3}$ Ditinjau dari segi tata negara, kekuasaan kehakiman identik dengan badan "yudikatif". Menurut pasal 24 ayat (1), kekuasaan kehakiman dilakukan oleh sebuah Mahkamah Agung dan lainlain badan kehakiman menurut Undang-Undang. Kemudian dalam penjelasan pasal 24 dan 25 ditegaskan: ${ }^{4}$

"Kekuasaan kehakiman kekuasaan yang merdeka, artinya terlepas dari pengaruh kekuasaan pemerintah. Berhubung dengan itu, harus diadakan jaminan dalam Undang-Undang tentang kedudukan para hakim".

Penjelasan pasal tersebut dikemukakan bahwa kekuasaan kehakiman yang merdeka mengandung pengertian bebas dari campur tangan pihak kekuasaan lainnya. Walaupun demikian, kebebasan itu sifatnya tidak mutlak karena hakim bertugas menegakkan hukum dan keadilan dengan jalan menafsirkan hukum dan mencari dasar serta asas-asas yang menjadi landasannya melalui perkara-perkara yang diproses di pengadilan sehingga putusannya mencerminkan perasaan keadilan masyarakat. ${ }^{5}$

Terkait dengan hukum sebagai alokasi sistem (law as an allocative system) Lawrence M. Friedman ${ }^{6}$ menuliskan bahwa :

"What is this justice that, in the broadest sense, the legal system must produce? The concept. Of course, defies definition, and it is the subject of a wide philosophical literature. For our purposes, it

1 Sophar Malu Hutagalung, Praktik Peradilan Perdata (Teknis Menangani Perkara di Pengadilan), (Jakarta: Sinar Grafika, 2011), hlm. 5.

${ }^{2}$ Pasal 1 UU No. 48 Tahun 2009 tentang Kekuasaan Kehakiman.

3 Jaenal Arifin, Peradilan Agama dalam Bingkai Reformasi Hukum di Indonesia (Jakarta: Kencana, 2008), hlm. 140.

${ }^{4}$ M. Yahya Harahap, Kedudukan Kewenangan dan Acara Peradilan Agama UU NO. 7 Tahun 1989 (Jakarta: Sinar Grafika, 2009), hlm. 98.

${ }^{5}$ Cik Hasan Bisri, Peradilan Agama di Indonesia (Jakarta: Raja Grafindo Persada, 1998), hlm. 143-145.

${ }^{6}$ Lawrence M. Friedman, The Legal System : A Social Science Perpective, (New York: Russel Sage Foundation, 1975), hlm. 20. 
refers to expectations and assesments. People in a society expect the law to meet their ethical standards. They will judge it on how it performs. By "performs" we mean, how it treats people and how it distributes its benefits and costs."

Secara bebas diterjemahkan bahwa "dalam pengertian umum, seperti apa keadilan yang hendak wujudkan sistem hukum?. Tentunya, sulit mendefinisikan konsepsi keadilan dan selama ini sebatas menjadi kajian dalam berbagai literatur filsafat. Untuk tujuan kita, makna keadilan lebih mengacu pada pengharapan dan penilaian masyarakat. Masyarakat menilai hukum yang adil adalah yang sesuai dengan standar etis mereka. Menilainya dari bagaimana hukum itu bekerja. Yaitu, perlakuan hukum terhadap orang dan bagaimana pendistribusian hukum terhadap keuntungan dan kerugian."

Terlepas dari penolakan terhadap pendefinisian hukum oleh Salmond ${ }^{7}$ sebagai "the body of principles recognized and applied bye the state in the administration of justice," tetapi keadilan merupakan penekanan yang menonjol dalam menitikberatkan tujuan berhukum, demikian pula meskipun legal utilitarisme Bentham ${ }^{8}$ secara tegas menjadikan doktrin kemanfaatan hukum sebagai aras utama berhukum, tetap saja kemanfataan tersebut sedapat mungkin mengurangi praktik-praktik ketidakadilan.

Keadilan dalam teori hukum klasik yang dikembangkan pemikir barat dengan teori etisnya merupakan tujuan utama, sedangkan aliran positivisme (legalistik) berkiblat kepada kepastian. Adapun teori-teori hukum modern menempatkan keadilan, kemanfaatan dan kepastian hukum sebagai standar baku dalam tujuan hukum, dan secara kasuistis, ketiga tujuan tersebut dapat berdiri sendiri atau berdasarkan skala prioritas menempati urutannya masing-masing secara proporsional. ${ }^{9}$ Namun demikian, di antara teori-teori yang dikembangkan para pemikir hukum dan kenegaraan sejak jaman yunani kuno, romawi, islam serta pemikir-pemikir hukum Indonesia kekinian tidak pernah melepaskan keadilan dari salah satu kondisi yang hendak diwujudkan oleh hukum.

Pasal 5 ayat (1) Undang-undang (UU) Nomor 48 Tahun 2009 tentang Kekuasaan Kehakiman ${ }^{10}$ menyebutkan bahwa hakim dan hakim konstitusi wajib menggali, mengikuti, dan memahami nilai-nilai hukum dan rasa keadilan yang hidup dalam masyarakat.

\footnotetext{
${ }^{7}$ Achmad Ali, Menguak Teori Hukum (legal theory) dan Teori Peradilan (judicialprudence) Termasuk Interpretasi Undang-Undang (Legisprudence), (Jakarta: Kencana Prenada Media Group, 2012), hlm. 73.

${ }^{8}$ Ibid., hlm. 78.

${ }^{9}$ Ibid., hlm. 213.

10 Lembaran Negara Republik Indonesia (LNRI) Tahun 2009 Nomor 157, Tambahan Lembaran Negara Republik Indonesia (TLNRI) Nomor 5076.
} 
Menurut Romli Antasasmita ${ }^{11}$ norma tersebut, yaitu:

"...Aspek sosiologis mengandung makna bahwa hakim harus peka dan tanggap terhadap nilai keadilan yang berkembang dalam masyarakat. Sedangkan secara teleologis, mengandung makna bahwa hakim harus memahami tujuan pembentukan suatu undangundang dan tujuan umum dari hukum yaitu memelihara ketertiban, kepastian hukum dan keadilan serta kemanfaatan dalam suatu rangkaian sistematis yang sepatutya tercermin dalam putusan pengadilan.."

Lebih dari itu, dalam Pasal 197 ayat (1) huruf a UU Nomor 8 Tahun 1981 tentang Hukum Acara Pidana ${ }^{12}$ menyaratkan pencantuman pada kepala (irah-irah) setiap vonis hakim tulisan "DEMI KEADILAN BERDASARKAN KETUHANAN YANG MAHA ESA" dan apabila disimpangi maka putusan dimaksud menjadi batal demi hukum.

Namun demikian, sudut pandang dan makna keadilan bagi masyarakat dalam menilai setiap perundang-undangan, dan ataupun putusan pengadilan adalah berdasarkan pada standar etik yang mereka pahami sebagai sebuah keharusan yang memang harusnya demikian sebuah norma yang diterapkan. Kontekstualisasi pemaknaan demikian salah satunya tercermin dari penolakan 31 (tiga puluh satu) orang hakim agung terhadap keterlibatan Komisi Yudisial (KY) melakukan pengawasan terhadap hakim Mahkamah Agung (MA) yang kemudian mereka berusaha menarik hakim Mahkamah Konstitusi (MK) sebagai bagian yang tidak dapat pula diawasi KY, sehingga muncullah Putusan MK Nomor 005/PUU-IV/2006 tentang Pengujian Undang-undang Nomor 22 Tahun 2004 tentang Komisi Yudisial dan Undang-undang Nomor 4 tahun 2004 tentang Kekuasaan Kehakiman, yang substansinya justru menguatkan peran KY dalam mengawasi hakim MA dan hakim-hakim yang ada di bawah lingkungan MA serta mengecualikan hakim MK dari pengawasan KY.

Mengingat terjadinya kekosongan hukum pengawasan yang dilakukan KY sebagai akibat ketidakpastian hukum pelaksanaan kegiatan tersebut, ${ }^{13}$ DPR bersama presiden melakukan perubahan terhadap paket UU kekuasaan Kehakiman sebagaimana disarankan dalam putusan MK.

11 Romli Antasasmita, Teori Hukum Integratif : Rekonstriksi terhadap Teori Hukum Pembangunan dan Teori Hukum Progressif, (Yogyakarta: Genta Publishing, 2012), hlm. 39.

${ }^{12}$ Lembaran Negara Republik Indonesia Tahun 1981 Nomor 76, Tambahan Lembaran Negara Republik Indonesia Nomor 3209.

${ }^{13}$ Lihat Putusan MK No. 005/PUU-IV/2006 tentang Pengujian Undang-undang Nomor 22 Tahun 2004 tentang Komisi Yudisial dan Undang-undang Nomor 4 tahun 2004 tentang Kekuasaan Kehakiman, hlm. 200-201. 
Undang-undang paket kekuasaan kehakiman yang mengalami penggantian adalah UU No. 4 Tahun 2004 tentang Kekuasaan Kehakiman ${ }^{14}$ menjadi UU Nomor 48 Tahun 2009 tentang Kekuasaan Kehakiman, yang kemudian disusul dengan perbaikan UU No. 24 Tahun 2003 tentang Mahkamah Konstitusi ${ }^{15}$ dengan UU No. 8 Tahun 2011 tentang Perubahan UU Nomor 24 Tahun 2003 tentang Mahkamah Konstitusi ${ }^{16}$ dan terakhir perbaikan UU KY dengan UU Nomor 18 Tahun 2011 tentang Perubahan Undang-Undang Nomor 22 Tahun 2004 tentang Komisi Yudisial. ${ }^{17}$

Pengawasan terhadap hakim yang dilakukan KY sebagaimana diatur dalam UU Kekuasaan Kehakiman 2004, dan perubahan UU KY 2011 diakui sebagai hukum yang sesuai dengan kehendak Pasal 24B UUD 1945. Namun demikian, terkait pengawasan yang dilakukan Majelis Kehormatan Mahkamah Konstitusi "yang dua anggotanya berasal dari unsur DPR dan pemerintah", terhadap hakim konstitusi sebagaimana diatur dalam Pasal 27A ayat (2) UU Nomor 8 Tahun 2011, yang sejatinya merupakan penjabaran lebih lanjut dari Pasal 23 UUMK dan Pasal 44 UU Kekuasaan Kehakiman oleh sejumlah pemikir ketatanegaraan Indonesia dipandang sebagai pilihan politik yang dapat mempengaruhi independensi MK, karenanya harus dinyatakan bertentangan dengan UUD 1945. Sudut pandang sejumlah pakar tersebut kemudian bermuara pada inskonstitusionalitas Majelis Kehormatan Hakim Konstitusi sebagai organ pengawas hakim MK sebagaimana terdapat dalam Putusan MK No. 049/PUU-IX/2011 tentang Pengujian Undangundang Nomor 8 Tahun 2011 tentang Perubahan UU No. 24 Tahun 2003 tentang Mahkamah Konstitusi terhadap UUD 1945.

Penghapusan organ pengawas hakim konstitusi dalam Pasal 27A ayat (2) UU MK, oleh MK ditindaklanjuti dengan penerbitan Peraturan MK Nomor 1 Tahun 2013 tentang Majelis Kehormatan Mahkamah Konstitusi yang didasarkan pada Pasal 27A ayat (7) UUMK yang menyatakan bahwa ketentuan lebih lanjut mengenai susunan, organisasi, dan tata beracara persidangan Majelis Kehormatan Mahkamah Konstitusi diatur dalam Peraturan Mahkamah Konstitusi.

Namun demikian, perubahan organ pengawas hakim kostitusi yang benar-benar tidak lagi melibatkan unsur politik dan pemerintah juseru tidak diikuti dengan kesadaran tinggi penegakan etik individu hakim konstitusi

\footnotetext{
${ }^{14}$ Lembaran Negara Republik Indonesia Tahun 2004 Nomor 8, Tambahan Lembaran Negara Republik Indonesia Nomor 4358.

${ }^{15}$ Lembaran Negara Republik Indonesia Tahun 2004 Nomor 98, Tambahan Lembaran Negara Republik Indonesia Nomor 43316.

${ }^{16}$ Lembaran Negara Republik Indonesia Tahun 2011 Nomor 70, Tambahan Lembaran Negara Republik Indonesia Nomor 5226.

${ }^{17}$ Lembaran Negara Republik Indonesia Tahun 2011 Nomor 106, Tambahan Lembaran Negara Republik Indonesia Nomor 5250.
} 
sehingga terjadilah penangkapan M. Akil Mochtar yang diduga terlibat dalam pengaturan putusan sengketa pemilihan kepala daerah yang disidangkan MK. Mahkamah yang semula berada pada puncak kehormatan sebagai lembaga negara yang bebas dari berbagai praktik mafia hukum mengalami degradasi dan kehilangan kepercayaan publik, sehingga kemudian pemerintah mengeluarkan Peraturan Pemerintah Pengganti Undang-Undang (Perpu) No. 1 Tahun 2013 tentang Perubahan Kedua atas Undang-Undang Nomor 24 Tahun 2003 tentang Mahkamah Konstitusi, yang kemudian ditetapkan DPR menjadi Undang-Undang Nomor 4 Tahun 2014 Penetapan Peraturan Pemerintah Pengganti Undang-Undang Nomor 1 Tahun 2013 tentang Perubahan Kedua atas Undang-Undang Nomor 24 Tahun 2003 tentang Mahkamah Konstitusi menjadi Undang-Undang. ${ }^{18}$

Kegagalan pengawasan internal MK tersebut oleh Perpu dijadikan pintu masuk mengembalikan keterlibatan KY dalam pembentukan organ pengawas hakim konstitusi bersama MK, serta penyusunan dan menetapkan Kode Etik dan Pedoman Perilaku Hakim Konstitusi dengan membentuk Majelis Kehormatan Mahkamah Konstitusi yang sekretariatnya berkedudukan di KY, bahkan disebutkan bahwa ketentuan lebih lanjut mengenai kode etik dan pedoman perilaku hakim konstitusi, tata cara pemilihan Majelis Kehormatan Hakim Konstitusi, susunan organisasi dan tata kerja Majelis Kehormatan Hakim Konstitusi diatur dengan Peraturan Bersama Mahkamah Konstitusi dan Komisi Yudisial.

Mengingat belum terbentuknya Majelis Kehormatan sebagaimana dimaksud Perpu, Mahkamah menerbitkan PMK Nomor 2 Tahun 2013 tentang Dewan Etik Mahkamah Konstitusi yang bekerja menjalankan tugas dan wewenang Majelis Kehormatan Hakim Konstitusi yang dibuat bersama MK dan KY.

Kehadiran KY yang terlibat dalam mendesain Majelis Kehormatan Mahkamah Konstitusi sebagaimana dimaksud Pasal 27A Perpu oleh sejumlah dosen dikategorikan sebagai tindakan pemerintah yang bertentangan dengan UUD 1945. Pada akhirnya, Perpu No. 1 Tahun 2013 yang ditetapkan menjadi UU No.4 Tahun 2014 dinyatakan bertentangan dengan UUD 1945 melalui Putusan MK No. 1-2/PUU-XII/2014 tentang Pengujian UU Nomor 4 Tahun 2014 tentang Penetapan Perpu No. 1 Tahun 2013 tentang Perubahan Kedua Atas UU Nomor 24 Tahun 2003 tentang Mahkamah Konstitusi terhadap UUD 1945. Atas dasar vonis tersebut, MK kemudian berdasarkan Pasal 23 UU MK menetapkan PMK No. 2 Tahun 2014 tentang Majelis Kehormatan Mahkamah Konstitusi yang mencabut dan

\footnotetext{
${ }^{18}$ Lembaran Negara Republik Indonesia Tahun 2014 Nomor 5, Tambahan Lembaran Negara Republik Indonesia Nomor 5493.
} 
menyatakan tidak berlaku PMK No. 1 Tahun 2013 dan PMK No. 2 Tahun 2013.

Fungsi dan kedudukan organ pengawas hakim sebagaimana uraianuraian tersebut di atas apabila dikaitkan dengan sudut pandang Friedman yang menjadikan fungsi hukum sebagai sistem alokasi menimbulkan beberapa permasalahan akademik antara lain, a) bagaimana hukum mengatur pengawasan hakim (How it performs)?; b) bagaimana hukum mengawasi hakim (How it treats people)?; c) perlakuan hukum bagaimanakah yang adil dalam mengawasi hakim (How it distribute) ?; dan d) Apakah mengawasi hakim dapat memberikan keuntungan atau justru merugikan (How its cost and benefit)?

Metode penelitian yang digunakan adalah teoretis dengan menggunakan pendekatan konsep dan perundang-undangan serta pendekatan case dengan mengaji abstraksi putusan Mahkamah Konstitusi tentang Pengawasan Hakim (Uji Materi UU KY).

\section{B. Pembahasan}

\section{Norma Hukum Pengawasan Hakim (How It Performs)}

Kekuasaan kehakiman yang dilaksanakan MA dan badan kehakiman lainnya merupakan salah satu lembaga negara yang sejak sebelum kemerdekaan telah eksis, yaitu Mahkamah Agung Pemerintah Hindia Belanda di Indonesia (Het Hooggerechtshoof vor Indonesia, selanjutnya ditulis HGH) yang didirikan dengan Reglement op de Rechtelijk Organisatie en het Beleid der Justitie (RO) tahun 1842. HGH merupakan peradilan kasasi (hof van Cassitie), dan pengadilan banding (Appel) bagi putusan Raad van Justietie (RV). ${ }^{19}$ Sedangkan bagi pribumi (inlander) atau yang dipersamakan, HGH merupakan RV, sebagai peradilan tingkat banding dan Landraad sebagai peradilan tingkat pertama. ${ }^{20}$ Masa Pendudukan Inggris, HGH menjadi Supreme Court of Justice yang berfungsi sebagai pengadilan apel putusan Court of Justice Semarang dan Surabaya. ${ }^{21}$

Sebagai pengadilan tertinggi, HGH juga bertugas/berwenang untuk:

a. mengawasi jalannya peradilan di seluruh Indonesia sehingga dapat berjalan secara patut dan wajar;

b. mengawasi perbuatan/kelakuan hakim serta pengadilan-pengadilan;

c. memberi teguran-teguran apabila diperlukan;

${ }^{19}$ A. Mukti Arto, Konsepsi Ideal MA ; Redefenisi Peran dan Fungsi Mahkamah Agung Untuk Membangun Indonesia Baru, (Yogyakarta: Pustaka Pelajar, 2001), hlm. 181.

${ }^{20}$ Wirjono Prodjodikoro, Azas-Azas Hukum Tatanegara Indonesia, (Jakarta: Dian Rakjat, 1983), hlm. 97.

21 http://72.14.235.104/search?q=cache:MPHopkLosFwJ:www.ma-ri.go.id/Html/Sejarah1_4 $. h t m+$ Penetapan+Pemerintah+Nomor+9/S.D+Tahun+1946\&hl=id\&ct=clnk\&cd=1\&gl=id, terakhir kali dikunjungi pada November 2014, jam . 13.25 WIB. 
d. berhak minta laporan, keterangan-keterangan dari semua pengadilan baik sipil maupun militer, Pokrol Jendral dan lain pejabat penuntut umum. ${ }^{22}$

Pasca kemerdekaan, berdasarkan Pasal II aturan Peralihan UUD 1945, kedudukan MA sederajat dengan DPR, Presiden, DPA, BPK, yang selanjutnya oleh TAP MPR Nomor VI/MPR/1973 jo TAP MPR Nomor III/MPR/1978 tentang Kedudukan dan Hubungan Tata-Kerja Lembaga Tertinggi Negara dengan/atau antar Lembaga -Lembaga Tinggi Negara disebut sebagai lembaga tinggi negara, serta ditegaskan Pasal 1 Undangundang Nomor 14 Tahun 1985 yang menyebutkan bahwa "Mahkamah Agung adalah Lembaga Tinggi Negara sebagaimana dimaksudkan dalam Ketetapan Majelis Permusyawaratan Rakyat Republik Indonesia Nomor III/MPR/1978."

Sebagai pejabat negara, hakim MA dipilih presiden berdasarkan daftar nama yang diusulkan DPR, sedangkan DPR mengajukan nama tersebut kepada presiden berdasarkan hasil kesepakatan dalam forum MA dan Departemen Kehakiman (Forum Mahdep). ${ }^{23}$ Dalam praktik, peranan departemen sangat menonjol dibandingkan MA, sehingga faktor kedekatan, suka tidak suka (like and dislike) dengan lingkungan eksekutif (presiden) menjadi salah satu pertimbangan pengisian jabatan hakim MA kala itu, yang berarti serupa dengan terjadinya campur tangan eksekutif. Namun demikian, berbeda dengan pemilihan di Amerika, meskipun tidak semua menjadi hakim agung, Indonesia lebih mendekati sistem Perancis yang sama-sama berbasis hukum sipil. Hakim Indonesia merupakan jabatan karir yang diangkat presiden, direkrut dengan proses seleksi dari alumni fakultas hukum oleh departemen atas usul (permintaan) $\mathrm{MA},{ }^{24}$ serta mengikuti pelatihan (pendidikan) sebelum menjalankan tugasnya. Meskipun berkedudukan sebagai pejabat kekuasaan kehakiman, ${ }^{25}$ hakim merupakan Pegawai Negeri Sipil (PNS) yang tunduk pada pengawasan eksekutif (departemen), sedangkan teknis yudisial diawasi MA. ${ }^{26}$ Konsekuensinya,

${ }^{22}$ Ibid.

23 Lihat Pasal 8 Undang-Undang Nomor 14 Tahun 1985 tentang Mahkamah Agung (Lembaran Negara Republik Indonesia Tahun 1985 Nomor 73, Tambahan Lembaran Negara Republik Indonesia Nomor 3316).

${ }^{24}$ Lihat Pasal 16 Undang-Undang Nomor 2 Tahun 1986 (Lembaran Negara Republik Indonesia Tahun 1986 Nomor , TLN Nomor ), jo Pasal 16 Undang-Undang Nomor 5 Tahun 1986, Pasal 15 Undang-Undang Nomor 7 Tahun 1989, Pasal 21 Undang-Undang Nomor 31 Tahun 1997.

${ }^{25}$ Lihat Pasal 12 (1) Undang-Undang Nomor 2 Tahun 1986, jo Pasal 12 (1) Undang-Undang Nomor 5 Tahun 1986, Pasal 11 (1) Undang-Undang Nomor 7 Tahun 1989, Pasal 5 (1) Undang-Undang Nomor 31 Tahun 1997.

${ }^{26}$ Lihat Pasal 5 Undang-Undang Nomor 2 Tahun 1986, jo Pasal 7 Undang-Undang Nomor 5 Tahun 1986, Pasal 5 Undang-Undang Nomor 7 Tahun 1989, Pasal 6 Undang-Undang Nomor 31 Tahun 1997. 
meskipun diberhentikan sebagai hakim, tidak serta merta berhenti sebagai PNS. ${ }^{27}$

Kewenangan MA, pada prinsipnya memiliki kesamaan dengan $\mathrm{HGH}$, sebagai pengadilan tertinggi, ${ }^{28}$ wewenang pengawasan dan pembinaan teknis yudisial serta perbuatan badan peradilan dan hakim, ${ }^{29}$ serta wewenang lain yang diatur undang-undang. ${ }^{30}$ Namun demikian, pembinaan organisasi, administrasi, keuangan badan peradilan di bawah MA merupakan kewenangan departemen terkait.

Pasca perubahan empat kali UUD Tahun 1945, struktur organisasi negara dibentuk dengan separation of power menempatkan MA dan lembaga negara lainnya sederajat, tidak lagi terdapat nomenklatur lembaga tinggi dan tertinggi negara. Secara radikal, hakim di semua tingkatan merupakan pejabat negara, dengan pembinaan dan pengawasan teknis yudisial dan non yudisial berada dalam kendali $\mathrm{MA} / \mathrm{MK}^{31}$ sebagai wujud peradilan satu atap (one roof system) terdapat hakim non-karir di $\mathrm{MA}^{32}$ ataupun dalam lingkungan peradilan dibawahnya, ${ }^{33}$ serta MK. ${ }^{34}$ Di samping itu, untuk menjaga agar peradilan dijalankan secara seksama dan sewajarnya, ketua pengadilan negeri dan banding melakukan pengawasan terhadap pelaksanaan tugas dan tingkah laku hakim. ${ }^{35}$

Akan tetapi, untuk tidak terjadi semangat melindungi lembaga dan penyalahgunaan independensi dalam menjalankan wewenangnya, pengawasan perilaku hakim tidak lagi merupakan monopoli lembaga peradilan, melainkan dibentuk organ konstitusi lain, Komisi Yudisial (KY), yang berwenang "mengusulkan pengangkatan hakim agung dan memunyai wewenang lain dalam rangka menjaga dan menegakkan kehormatan, keluhuran martabat, serta perilaku hakim." ${ }^{36}$ Penggalan anak kalimat “...wewenang lain dalam rangka menjaga dan menegakkan kehormatan, keluhuran martabat, serta perilaku hakim" selanjutnya diterjemahkan Undang-undang Nomor 4 Tahun 2004 dan Undang-Undang Nomor 22

${ }^{27}$ Lihat Pasal 21 Undang-Undang Nomor 2 Tahun 1986, jo Pasal 21 Undang-Undang Nomor 5 Tahun 1986, Pasal 20 Undang-Undang Nomor 7 Tahun 1989.

${ }^{28}$ Lihat Pasal 2, jo Pasal 28 - Pasal 31, Pasal 33, Pasal 34 UU MA.

${ }^{29}$ Lihat Pasal 32 UU MA.

${ }^{30}$ Lihat Pasal 35 - Pasal 39 UU MA.

${ }^{31}$ Lihat Pasal 31 UU KK.

${ }^{32}$ Pasal 7 (2, 3) UU KK.

${ }^{33}$ Lihat Pasal 2, jo Pasal 27-Pasal 29 Undang-undang Nomor 26 Tahun 2000 tentang Pengadilan Hak Asasi Manusia, Pasal 78 Undang-undang Nomor 31 Tahun 2004 tentang Pengadilan Perikanan.

${ }^{34}$ Lihat Pasal 16 dan Pasal 18 (1) UU MK.

${ }^{35}$ Lihat pasak $53(1,2)$ UUPU.

${ }^{36}$ Lihat Pasal 24B (1) UUD Tahun 1945. 
Tahun 2004 sebagai norma pengawasan perilaku hakim, ${ }^{37}$ dan norma tersebut berlaku serupa bagi hakim di Mahkamah Konstitusi.

Di samping pengawasan dilakukan organ konstitusi tersebut, terhadap perbuatan dan pelayanan umum pejabat publik termasuk badan peradilan, terdapat pengawasan dengan melibatkan peran serta masyarakat yang dilakukan Komisi Ombudsman Nasional (KON)..$^{38}$

Pada perkembangannya, meskipun Pasal 24C ayat (1) UUD 1945 oleh UU KK 2004 dan UU KY 2004 diartikan wewenang pengawasan KY termasuk terhadap hakim MK dan hakim agung serta seluruh hakim di lingkungan badan peradilan di lingkungan MA, tetapi 31 (tiga puluh satu) hakim MA mengajukan judicial review terhadap UU KY dan UU KK yang kemudian lahir Putusan MK No. 005/PUU-IV/2006 yang justru di luar permintaan para hakim agung tersebut, yaitu menyatakan hakim MA dan hakim-hakim yang berada dalam lingkungan MA sebagai objek pengawasan KY sedangkan Hakim Konstitusi tidak dapat diawasi KY.

Putusan Mahkamah menyatakan bahwa :

“...hakim konstitusi tidak termasuk dalam pengertian hakim yang perilaku etiknya diawasi oleh Komisi Yudisial. Pengawasan terhadap pelaksanaan kode etik hakim konstitusi dilakukan oleh Majelis Kehormatan yang tersendiri sesuai dengan ketentuan Pasal 23 UUMK sebagai pelaksanaan Pasal 24C ayat (6) UUD 1945. Untuk seterusnya, kedudukan Mahkamah Konstitusi sebagai lembaga pemutus sengketa kewenangan lembaga negara yang kewenangannya diberikan oleh undang-undang dasar, termasuk sengketa yang melibatkan KY dan MA, tidak lagi terganggu sebagai akibat diperluasnya pengertian hakim yang meliputi hakim konstitusi dimaksud. Hal demikian secara langsung berkaitan pula dengan kepentingan para Pemohon sendiri untuk adanya penyelesaian konstitusional atas permasalahan yang dihadapi dalam hubungan antara MA dan KY, yang sekiranya permohonan mengenai hakim konstitusi ini tidak dikabulkan, niscaya kredibilitas dan legitimasi Mahkamah Konstitusi sendiri dalam memeriksa, mengadili, dan memutus perkara a quo dapat terusmenerus dipertanyakan." 39

Sedangkan wewenang KY mengawasi Hakim Agung dan hakim dalam lingkungan badan peradilan di MA oleh putusan MK disebutkan bahwa :

“... Persoalan yang berkaitan dengan pertanyaan apakah hakim menurut Pasal 24B ayat (1) UUD 1945 meliputi pengertian hakim

\footnotetext{
${ }^{37}$ Lihat Pasal 13 huruf b, jo Pasal 20-Pasal 25.

${ }^{38}$ Lihat Keputusan Presiden Nomor 44 Tahun 2000 tentang Komisi Ombudsman Nasional.

${ }^{39}$ Putusan MK Nomor 005/PUU-IV/2006, hlm. 199.
} 
agung atau tidak, tidaklah dapat ditemukan dasar-dasar konstitusional yang meyakinkan. Pembentuk undang-undang dapat saja menentukan bahwa untuk kepentingan pembinaan bertahap dan untuk kepentingan jangka panjang berdasarkan pertimbangan teleologis bahwa di masa depan apabila seluruh hakim agung sudah merupakan produk rekruitmen oleh KY maka untuk pengawasan cukuplah bagi KY mengurusi perilaku etik para hakim di bawah hakim agung. Sekiranya undang-undang menentukan hal demikian, Mahkamah Konstitusi berpendapat bahwa hal itu tidaklah bertentangan dengan UUD 1945. Namun sebaliknya, jika undang-undang menentukan bahwa hakim agung termasuk ke dalam pengertian hakim yang perilaku etiknya diawasi oleh KY secara eksternal, sebagaimana telah dijelaskan dalam uraian di atas, maka Mahkamah Konstitusi berpendapat bahwa hal itu pun tidak bertentangan dengan UUD 1945. Apalagi, para hakim agung yang ada sekarang juga tidak direkrut berdasarkan ketentuan baru yang melibatkan peran KY sebagaimana ditentukan dalam UUD 1945. Pilihan kebijakan hukum yang demikian, menurut Mahkamah Konstitusi, juga tidak bertentangan dengan UUD $1945 .{ }^{40}$

Putusan MK oleh DPR dan Pemerintah ditindaklanjuti dengan penggantian UU KK 2004 menjadi UU KK No. 48 Tahun 2009 yang diteruskan dengan perubahan UU KY dengan UU No. 18 Tahun 2011.

Pengawasan hakim dalam UU KK Tahun 2004 yang semula terdapat dalam Pasal 34 ayat (3) dihapus dengan membuat rumusan pengawasan yang lebih terperinci sebagaimana diatur dalam Pasal 40-43 UU KK Tahun 2009. Sedangkan perubahan yang signifikan dalam UU KY No. 18 Tahun 2011 adalah dengan menghilangkan wewenang mengusulkan penjatuhan sanksi hakim MK kepada ketua MK sebagaimana semula terdapat dalam Pasal 21 UU KY Tahun 2004. Di samping itu, prosedur pengawasan KY terhadap hakim MA dan badan peradilan di lingkungan MA lebih dipertegas prosedur atau mekanisme pengawasan tersebut dalam UU KY Tahun 2011. Sedangkan pengawasan hakim MK secara exvressis verbis dalam Pasal 44 UU KK Tahun 2009 dikembalikan kepada mekanisme Majelis Kehormatan Hakim Konstitusi sebagaimana terdapat dalam Pasal 23 UU MK.

\section{Prosedur Pengawasan Hakim (How It Treats People)}

Adapun tolok ukur pengawasan perilaku hakim selain dalam bentuk syarat administratif kelayakan jabatan, norma larangan-larangan tertentu disertai sanksi dalam undang-undang paket kekuasaan kehakiman, juga terdapat dalam Kode Kehormatan Hakim (KKH) Tahun 1966, yang

\footnotetext{
${ }^{40}$ Ibid., hlm. 199-200.
} 
selanjutnya disempurnakan dalam Musyawarah Nasional (MUNAS) XIII Ikatan Hakim Indonesia (IKAHI) 2002. Hanya saja, KKH tersebut bersifat umum (general) dan tidak aflikatif.

Amanat Undang-Undang Nomor 35 Tahun 1999 tentang Perubahan Atas Undang-Undang Nomor 14 Tahun 1970 Tentang Ketentuan-Ketentuan Pokok Kekuasaan Kehakiman yang melegitimasi Dewan Kehormatan Hakim (DKH) menyusun kode etik (code of conduct) bagi hakim, serta berwenang mengawasi perilaku hakim, memberikan rekomendasi mengenai perekrutan, promosi, dan mutasi hakim, meskipun KY menyusun code of conduct, pada akhirnya pimpinan MA mengeluarkan surat keputusan Nomor 104A/SK/XII/2006 tanggal 22 Desember 2006 tentang Pedoman Perilaku Hakim (PPH). Berbeda dengan PPH Amerika Serikat yang hanya memuat 7 Canon dengan 26 penjabaran, PPH MA mengandung 10 (sepuluh) prinsip dengan 24 (dua puluh empat) poin penjabaran. ${ }^{41}$

PPH MA tidak menyebutkan secara tersurat jenis sanksi yang akan dijatuhkan kepada hakim yang tidak mematuhinya, kecuali bagian D angka 3 $\mathrm{PPH}$ yang secara fakultatif menyebutkan :

Pelanggaran terhadap Pedoman ini dapat diberikan sanksi. Dalam menentukan yang layak dijatuhkan, harus dipertimbangkan faktor-faktor yang berkaitan dengan pelanggaran, yaitu latar belakang, tingkat keseriusan, dan akibat dari pelanggaran tersebut terhadap lembaga peradilan ataupun pihak lain.

Jenis sanksi yang dapat dijatuhkan kepada hakim dalam proses akhir pengawasan justru ditemukan dalam Undang-Undang Nomor 22 Tahun 2004, yaitu berupa teguran tertulis, pemberhentian sementara, atau pemberhentian. ${ }^{42}$ Tetapi, ini tidak dapat diartikan secara mutatis mutandis sebagai bentuk sanksi terhadap pelanggaran PPH yang dibuat MA. Melainkan sanksi yang dapat diusulkan KY kepada MA. Selain itu, bentuk sanksi terhadap hakim dalam menjalankan tugasnya dapat ditemukan dalam undang-undang paket kekuasaan kehakiman. ${ }^{43}$ Namun demikian, jenis sanksi yang disebutkan terakhir inipun secara tegas merujuk jenis pelanggaran yang dikualifikasikan oleh undang-undang itu sendiri, artinya tidak serta dapat dikategorikan sebagai salah satu yang dikualifikasikan PPH, dan bahkan terhadap sanksi pemberhentian tetap tidak dengan hormat disebabkan melakukan perbuatan yang tercela oleh undang-undang "perbuatan tercela"

41 Kesepuluh prinsip dimaksud adalah (1) berperilaku adil, (2) berperilaku jujur, (3) berperilaku arif dan bijaksana, (4) bersikap mandiri, (5) berintergasi tinggi, (6) bertanggungjawab, (7) menjunjung tinggi harga diri, (8) berdisiplin tinggi, (9) berperilaku rendah hati, dan (10) bersikap profesional.

${ }^{42}$ Lihat Pasal 23 (1) Undang-undang Nomor 22 Tahun 2004.

${ }^{43}$ Lihat Pasal 11 (1) jo Pasal 12 (1) UUMA, Pasal 19 (1) dan Pasal 20 (1) UUPU, Pasal 19(1) dan Pasal 20(1) UUPTUN, Pasal 18(1) dan Pasal 19(1) UUPA. 
diartikan sebagai perbuatan atau sikap, baik di dalam maupun di luar pengadilan yang dapat merendahkan martabat hakim. ${ }^{44}$

Implementasi pengawasan di lapangan secara internal dilakukan MA dengan membentuk Badan Pengawasan (BP) MA berdasarkan surat keputusan Ketua MA No. KMA/080/SK/VIII/2006 tentang Pedoman Pelaksanaan Pengawasan di Lingkungan Lembaga Peradilan, dan dilakukan dengan cara pengawasan rutin/reguler, pengawasan keuangan dan penanganan pengaduan sebagai bentuk pengawasan fungsional BP MA. Di samping itu, terdapat pengawasan melekat dari atasan langsung (Ketua PN/Banding) yang didasarkan Pasal 53 UUUPU, serta Keputusan Ketua MA Nomor KMA/096/SK/X/2006 tentang Tanggung Jawab Ketua Pengadilan Banding dan Ketua Pengadilan Tingkat Pertama dalam Melaksanakan Tugas Pengawasan.

Pasca penghapusan wewenang KY mengawasi hakim MK dalam Putusan MK No. 005/PUU-IV/2006 yang kemudian perbaikan UUKY dan penggantian UU KK 2004, mekanisme pengawasan hakim berdasarkan UUKK dilakukan sekaligus antara MA dan KY. Secara internal MA mengawasi perilaku para hakim sekaligus sebagai bentuk pembinaan, sedangkan dalam bidang yudisial MA melakukan pengawasan melalui mekanisme upaya hukum, baik upaya hukum biasa dan upaya hukum luar biasa. Namun demikian, pengawasan tersebut tidak dapat dijadikan sebagai cara untuk mengganggu kemerdekaan hakim dalma melaksanakan tugasnya.

Pengawasan hakim secara eksternal dilakukan KY berdasarkan ketentuan Pasal 40 UUKK, yang pelaksanaan pengawasan tersebut dilandaskan pada kode etika dan pedoman perilaku hakim yang dibuat bersama antara MA dan KY. Namun demikian, KY dapat melakukan analisis terhadap putusan hakim yang sudah final sebagai dasar pelaksanaan mutasi hakim yang bersangkutan. Prosedur pengawasan oleh KY terhadap lebih lanjut dijabarkan dalam UU KY Tahun 2011, yang pada prinsipnya KY dalam melakukan pengawasan terhadap hakim berdasarkan Pasal 20 ayat (1) UU KY, memunyai tugas untuk:

a. melakukan pemantauan dan pengawasan terhadap perilaku hakim;

b. menerima laporan dari masyarakat berkaitan dengan pelanggaran kode etik dan/atau pedoman perilaku hakim;

c. melakukan verifikasi, klarifikasi, dan investigasi terhadap laporan dugaan pelanggaran kode etik dan/atau pedoman perilaku hakim secara tertutup;

d. memutuskan benar tidaknya laporan dugaan pelanggaran kode etik dan/atau pedoman perilaku hakim; dan

${ }^{44}$ Lihat Penjelasan Pasal 12 (1) huruf b UUMA, Penjelasan Pasal 20(1) huruf b UUPU, Penjelasan Pasal 20(1) huruf b UUPTUN, Penjelasan Pasal 19(1) huruf b UUPA. 
e. mengambil langkah hukum dan/atau langkah lain terhadap orang perseorangan, kelompok orang, atau badan hukum yang merendahkan kehormatan dan keluhuran martabat hakim.

Di samping itu, untuk menjaga kebenaran prosesi pengawasan terkait dengan laporan atau informasi pelanggaran etika dan pedoman perilaku hakim, KY dapat meminta data atau informasi kepada badan peradilan terkait, dan peradilan tidak dapat menolak permintaan tersebut. Dalam proses pengawasan hakim tersebut, apabila ditemukan dan terbukti bahwa hakim terduga atau terlapor melakukan pelanggaran kode etik dan pedoman perilaku hakim yang berakibat pada pemberhentian tetap dengan pensiun atau pemberhentian tetap dengan tidak hormat, maka pemberhentian tersebut harus diusulkan KY kepada Majelis Kehormatan Hakim sebagaimana dijabarkan dalam Pasal 22B sampai dengan Pasal 25 UU KY.

\section{Perlakuan Adil dalam Mengawasi Hakim (How It Distribute)}

Keadilan adalah konsep abstrak, sehingga setiap sudut pandang dapat memberikan justfikasi adil dengan logika dan argumentasi masing-masing. Alam pikiran politik kenegaraan mengartikulasikan keadilan sebagai pencapai-pencapaian yang diberikan atau terkait dengan hak-hak politik yang diberikan negara. Namun demikian, keadilan dapat berarti ukuran yang diberikan atau ditentukan undang-undang. Di lain pihak, adil dapat berarti pencapaian kesuksesan yang diraih, atau dapat berarti pemerataan pendapatan atau bagian-bagian tertentu tanpa mempertimbangkan prestasi ataupun kedudukan dalam kelompok. Bagi perdagangan, adil justru berarti nilai keseimbangan antara pemberian dan penerimaan dari dua belah pihak dalam bertransaksi. Dalam kontek pidana klasik, adil berarti penggantian nyawa dengan nyawa, anggota badan dengan anggota badan yang serupa. Demikian pula pandangan berbeda, menjadi atau disebut adil manakala setiap orang diberikan bagian sesuai tanggung jawab atau proporsionalitas dan profesionalisme yang bersangkutan. Karenanya menjadi benar apa yang dituliskan N.E. Algra sebagaimana dikutip Ahmad $\mathrm{Ali}^{45}$ yang menyebutkan bahwa "...rechtvaardig, lebih banyak tergantung pada rechtmatigheid (kesesuaian dengan hukum) pandangan seorang penilai..."

Satjipto Rahardjo ${ }^{46}$ menuliskan bahwa :

"Sekalipun hukum itu langsung dihadapkan kepada pertanyaanpertanyaan yang praktis, yaitu tentang bagaimana sumber-sumber daya itu hendak dibagi-bagikan dalam masyarakat, tetapi ia tidak bisa terlepas dari pemikiran yang lebih absrak yang menjadi landasannya, yaitu pertanyaan tentang "mana yang adil" dan "apa

\footnotetext{
${ }^{45}$ Op.Cit., hlm. 222.

${ }^{46}$ Ibid., hlm. 223.
} 
keadilan itu?". Tatanan sosial, sistem sosial, dan hukum tidak bisa langsung menggarap tersebut tanpa diputuskan lebih dahulu tentang konsep keadilan oleh masyarakat yag bersangkutan. Kita juga mengetahui bahwa keputusan ini tidak bisa dilakukan oleh subsistem sosial, melainkan oleh subsistem budaya, seperti yang ditunjukkan dalam bagian sibernetika..."

Dalam pengawasan hakim sebagaimana dimaksud Pasal 24B ayat (1) UUD 1945 sebagaimana kemudian dijabarkan dalam UU KK, UU KY, UU MK serta UU paket kekuasaan kehakiman lain (UU PTUN, UU Pengadilan Umum, UU Pengadilan Agama) menimbulkan persoalan keadilan yang kemudian memunculkan perdebatan yuridis yang berakhir di MK sebagaimana dimaksud Putusan MK No. 005/PUU-IV/2006.

Bagi hakim MA pengawasan KY seharusnya hanya terhadap hakimhakim bukan hakim agung, tetapi terbatas hanya hakim-hakim di bawah dalam lingkungan MA (pengadilan negeri/agama, TUN, dan banding). Demikian pula, pengawasan KY tidak berlaku teradap hakim MK.

Pasal 24B ayat (1) UUD 1945 oleh MK dalam putusan a quo dipahami dalam satu tarikan nafas berbeda, wewenang menjaga kehormatan dan keluhuran hakim berada pada ranah KY yang disistematika pasalnya berada setelah pasal yang mengatur MA dan hakim-hakim dalam lingkungan MA. Sedangkan keberadaan hakim MK diatur setelah pengaturan wewenang KY, yaitu MK diatur dalam Pasal 24C UUD 1945. Dengan demikian, menjadi benar sudut pandang MK dalam putusan tersebut sebagai utusan yang adil apabila KY tidak mengawasi hakim MK. Lebih dari itu, Pasal 23 UU MK 2003 sama sekali menegasikan kehadiran KY dalam ranah pemberhentian dan/atau penjatuhan sanksi. Namun demikian, apabila dikaitkan dengan tertangkapnya M. Akil Mochtar oleh KPK, yang pada saat penangkapan merupakan ketua MK, sudut pandang MK dalam Putusan No. 005/PUU-IV/2006 dan No 49/PUU-IX/2011 justru menunjukkan dampak ketidakadilan dari penegasian hakim MK sebagai objek pengawasan KY.

Demikian pula pada saat kehadiran Perppu No. 1/2013 sebagai bentuk respon pemerintah atas kasus M. Akil Mochtar yang memberikan peluang keterlibatan KY dalam pembentukan Majelis Kehormatan Hakim Konstitusi oleh MK diartikan sebagai kemunduran penegakan hukum pengawasan KY, yang menurut MK bertentangan dengan yurisprundensi MK melalui Putusan Nomor 1-2/PUU-XII/2014. Dalam kondisi demikian, nampak adanya praktik ketidakadilan perlakukan pengawasan terhadap hakim di lingkungan MA dan lembaga peradilan di bawahnya dengan hakim Konstitusi yang cukup diawasi lembaga internal yang dibuat MK. 


\section{Penutup}

Berdasarkan analisis yang telah diuraikan, maka penulis menyimpulkan bahwa prosedur pengawasan hakim (How It Treats People) diatur dengan mekanisme internal oleh MA sebagai pembina institusi melalui mekanisme upaya hukum dan pengawasan perilaku, serta KY sebagai pengawas eksternal terhadap perilaku hakim agung dan hakim di bawah MA. Sedangkan hakim konstitusi diawasi secara internal tanpa keterlibatan lembaga luar. Terdapat ketidakadilan pengaturan norma pengawasan hakim (How It Distribute). Jika hakim agung dan badan peradilan dalam lingkungan MA diawasi secara eksternal oleh KY dan internal oleh MA, MK hanya diawasi lembaga buatan internal sendiri.

\section{Daftar Pustaka}

\section{A. Buku}

Ali, Achmad, 2012, Menguak Teori Hukum (legal theory) dan Teori Peradilan (judicialprudence) Termasuk Interpretasi Undang-Undang (Legisprudence), Kencana Prenada Media Group, Jakarta.

Arifin, Jaenal, 2008, Peradilan Agama dalam Bingkai Reformasi Hukum di Indonesia, Jakarta: Kencana.

Arto, A. Mukti, 2001, Konsepsi Ideal MA; Redefenisi Peran dan Fungsi Mahkamah Agung Untuk Membangun Indonesia Baru, Pustaka Pelajar, Yogyakarta.

Atmasasmita, Romli, 2012, Teori Hukum Integratif : Rekonstriksi terhadap Teori Hukum Pembangunan dan Teori Hukum Progressif, Yogyakarta: Genta Publishing

Bisri, Cik Hasan, 1998, Peradilan Agama di Indonesia, Jakarta: Raja Grafindo Persada.

Friedman, Lawrence M., 1975. The Legal System: A Social Science Perpective, Russel Sage Foundation, New York

Harahap, M. Yahya, 2009, Kedudukan Kewenangan dan Acara Peradilan Agama UU NO. 7 Tahun 1989, Jakarta: Sinar Grafika.

Hutagalung, Sophar Malu, 2011, Praktik Peradilan Perdata (Teknis Menangani Perkara di Pengadilan), Jakarta: Sinar Grafika.

Prodjodikoro, Wirjono, 1983, Azas-Azas Hukum Tatanegara Indonesia, Dian Rakjat, Jakarta.

\section{B. Peraturan Perundang-Undangan}

Undang-undang Nomor 14 Tahun 1985 tentang Mahkamah Agung. Undang-undang Nomor 2 Tahun 1986 tentang Peradilan Umum. 
Undang-undang Nomor 7 Tahun 1989 tentang Peradilan Agama.

Undang-undang Nomor 31 Tahun 1997 tentang Peradilan Militer.

Undang-undang Nomor 26 Tahun 2000 tentang Pengadilan Hak Asasi Manusia.

Undang-undang Nomor 31 Tahun 2004 tentang Pengadilan Perikanan.

Undang-undang Nomor 48 Tahun 2009 tentang Kekuasaan Kehakiman.

Keputusan Presiden Nomor 44 Tahun 2000 tentang Komisi Ombudsman Nasional.

Putusan MK No. 005/PUU-IV/2006 tentang Pengujian Undang-undang Nomor 22 Tahun 2004 tentang Komisi Yudisial dan Undang-undang Nomor 4 tahun 2004 tentang Kekuasaan Kehakiman.

\section{Karya Ilmiah}

Jayus, Jaja Ahmad, 2014, Hakim Sebagai Pejabat Negara, makalah diskusi publik LeIP, Jakarta.

\section{Internet}

Undang-undang Nomor 22 Tahun 2004.

http://www.kamusbesar.com/27136/nilai

http://www.kamusbesar.com/24813/manfaat

http://www.kamusbesar.com/9732/efisiensi

http://72.14.235.104/search?q=cache:MPHopkLosFwJ:www.ma-ri.go.id/Ht ml/Sejarah1_4.htm+Penetapan+Pemerintah+Nomor+9/S.D+Tahun+1 946\& $\mathrm{hl}=\mathrm{id} \& \mathrm{ct}=\mathrm{clnk} \& \mathrm{~cd}=1 \& \mathrm{gl}=\mathrm{id}$, terakhir kali dikunjungi pada November 2014, jam . 13.25 WIB. 